\title{
Innundative biocontrol of water hyacinth (Eichhornia crassipes (Mart.) Solms. Laubach) using zonate leaf spot (Acremonium zonatum Sawada Gams) fungal agent
}

\author{
George. O. Opande ${ }^{1}$, Chrispo. Mutebi ${ }^{2}$. Peter. F. Arama ${ }^{3}$, \\ ${ }^{I}$ Department of Botany, Maseno University, Private Bag, Maseno, Kenya \\ ${ }^{2}$ Kenya Agricultural Research Institute, Kibos Centre, Box 1490-40100, Kisumu, Kenya. \\ ${ }^{3}$ Department of Applied Sciences, Maseno University, Private Bag, Maseno, Kenya.
}

\begin{abstract}
Innundative approach of biocontrol involves culturing spore inoculum for use as a concentrated formulation able to withstand storage, handling and application in weed control the same way as a chemical herbicide. A trial was set up in Maseno University glass house to test the effect of concentrating and formulating A. zonatum spores in vegetable oil, mineral oil, pure commercial grade glycerol and tween 80 for use in water hyacinth biocontrol. A. zonatum was isolated from infected plants collected from Winam gulf (Lake Victoria) Kenya, cultured on PDA under aseptic conditions. The isolate was later multiplied on several PDA plates and spores harvested when mature, concentrated and formulated in 4 different oil emulsions. Fresh healthy water hyacinth plants were then collected from Winam gulf, injured and inoculated in a glass house in RCBD design, replicated 3 times. The results show that concentrating and formulating $A$. zonatum in vegetable oil and mineral oil may enhance its efficacy as a mycoherbicide, evidenced by the extensive leaf infection, though new leaves continued to form. A. zonatum concentrated and formulated can be used in the control of water hyacinth in the Winam gulf and L. Victoria in general. Suitability of an integrated approach with other insects should be investigated.
\end{abstract}

Keywords: Innundative, culturing, emulsions, formulating, infection, Winam-gulf, Lake Victoria.

\section{Introduction}

The water hyacinth is an invasive weed in the Winam gulf, Lake Victoria [1] therefore cheap long term self sustaining control strategies are not only necessary but a priority in view of the many negative socioeconomic attributes of this floating aquatic weed [1]. Fungal control agents have been considered for supplementing the various strategies that have so far been tried in the control of water hyacinth. In a study of potential fungal biocontrol agents [2], Acremonium zonatum appeared to be very virulent against water hyacinth though its infectivity was enhanced by increased moisture occasioned by covering up the plants after inoculation. The use of oil formulations has shown great promise for enhancing the efficacy of fungal agents that show potential as insecticides, fungicides and herbicides. Womack [3] investigated the use of less viscous vegetable oil suspension emulsions in the formulation of biocontrol agents. Water hyacinth is an invasive weed in ponds, rivers and lakes. It is easily propagated asexually by root and stems fragments and rapidly matures. It is a prolific seed producer with high seed germination rates. It is an economically important plant [1]. Water hyacinth, with its characteristic thick fringes and floating mats, has had serious impact on many aspects of life around various water bodies in the world ([1], [4], [5], [6], [7]). Impeding navigation, clogging waterways and water intake systems, fouling fishing traps, preventing access to landing sites, reducing light and oxygen so that plankton primary production and native fish die are some of the adverse conditions occasioned by water hyacinth [1].

The control of the water hyacinth in the Winam gulf using a cheap self sustaining method being a priority, this study was thus initiated to evaluate the efficacy of Acremonium zonatum formulated in; corn oil, mineral oil, glycerol and tween 80 in the innundative control of water hyacinth.

\section{Materials and Methods}

\subsection{Acquisition of infected plants and isolation of pathogen.}

Water hyacinth plants showing zonate leaf spot (A. Zonatum) symptoms were collected from Dunga and Kisumu airport beach. The plants were put in a big polythene bag containing water and ferried to the laboratory. At the laboratory, leaf pieces $\left(1 \mathrm{~mm}^{2}\right)$ were cut from the margins of necrotic lesions, surface disinfected in $0.5 \%$ sodium hypochlorite for 1 minute and transferred to $70 \%$ ethanol for 30 seconds. These were plated onto Potato Dextrose Agar (PDA) medium and incubated at room temperature. Upon sporulation, sub-culturing was done to obtain pure culture. 


\subsection{Identification of fungi}

This was done by microscopic examination of mycellial and conidial physical characteristics and using identification keys adopted from Olga [8]. Koch's Postulate (isolating fungus from plants showing disease symptoms, growing the isolate on pure culture and infecting the isolate upon healthy plants that then display symptoms characteristic of zonate leafspot) was also followed in the identification.

\subsection{Multiplication of fungi, harvesting and formulation}

Multiplication of inoculums was done by further sub culturing. When the sub-cultures showed signs of sporulation, the plates were flooded with $2 \mathrm{ml}$ of sterile water and the spores harvested by filtration through a nylon mesh cloth. A haemocytometer count chamber was used to prepare stock solutions containing $10^{8}, 10^{7}$, $10^{6}$ and $10^{5}$ spores $/ \mathrm{ml}$. adopting the method followed by Caprette [9]. $10 \mathrm{mls}$ of the stock solutions were added to $30 \mathrm{mls}$ of each of the different concentrations of corn oil, mineral oil, glycerol and $1 \%$ tween 80 .

\subsection{Inoculation of plants: Pathogenicity test}

Young plants with relatively small leaves and short petioles and of approximately the same age with 610 leaves per plant were selected. Individual plants were placed into $3 \mathrm{ft}$ plastic basins containing pond water and arranged in a randomized complete block design (RCBD). The young fully expanded leaves were injured by being slightly pricked 25 times using a sterile needle. Hand held sprayers positioned at $45^{\circ}$ and $20 \mathrm{~cm}$ from the plants were used to apply the innoculum, applying the lowest concentration $\left(10^{5}\right.$ spores $\left./ \mathrm{ml}\right)$ first and subsequently spraying the rest in ascending order. Spraying was done until the all the leaves surfaces were covered. A fine mist of sterile water was sprayed upon the leaves after the spray droplets had evaporated.

Disease scoring was done at 1 month after inoculum application using the scale adopted from Charudattan [10], and data analyzed.

\section{Results and Discussion}

Analysis of variance of the data showed that the means for interactions of spore concentration $\mathrm{x}$ oil formulation were not significantly different $(\mathrm{p}>0-05)$. Therefore, the different oil emulsions had the same effect on disease infection upon the hyacinth plants. Different concentrations of the inoculums in the different oil emulsions showed almost similar disease score levels, meaning lowering inoculums concentration will work just adequately.

Table 1: Disease score as affected by different concentrations of $A$. zonatum in different oil emulsions. Oil emulsion

\begin{tabular}{lllllllllll} 
& & $\mathbf{1 0}^{\mathbf{5}}$ & \multicolumn{1}{c}{$\mathbf{1 0}^{\mathbf{6}}$} & \multicolumn{10}{c}{$\mathbf{1 0}^{\mathbf{7}}$} & & $\mathbf{1 0}^{\mathbf{8}}$ & & Mean \\
Corn oil & 0 & & 20 & & 50 & & 50 & & 30.0 & \\
Glycerol & 0 & & 0 & & 20 & & 20 & & 10.0 & \\
Mineral oil & & 0 & & 0 & & 10 & & 10 & & 5.0 \\
Tween 80 & & 0 & & 0 & 0 & & 10 & & 2.5 &
\end{tabular}

The data showed that corn oil produced a slightly higher disease score than the rest of the oils. Mineral oil showed lower disease score result. This shows that concentration levels of the spore inoculums must be evaluated in order to find out the lowest observable adverse effect level (LOAEL) and/or lethal concentration 50 (LC50), two concentration parameters that can guide innundative use of $A$. zonatum as a mycoherbicide.

According to Womack [3], the use of less viscous vegetable oil in the formulation of fungal biocontrol agents has a clear advantage over the more viscous mineral oil. Formulation of fungal biocontrol agents with mineral oils overcomes the need to physically cover the infected leaves with polythene material to increase moisture for enhanced infection after inoculation. This study has further substantiated the findings of other workers ([3], [11] that oil encloses the moisture lost from the leaves making it become available to a fungal agent. It also provides the moist micro climate that is necessary for infection to effectively take place.

Formulating Acremonium zonatum spore suspension in mineral oil, tween 80 and glycerol was not as efficacious as it was in corn oil. Mineral or petroleum oils in their pure state have been reported to be used in plant disease control. They have been proved to have antifungal activity apart from being pesticidal. Wheeler [13] found that emulsified petroleum oils could be used in control of foliar fungal pathogens by suffocation or deprivation of oxygen from fungi and reduction of attachment of fungal spores to plant surfaces. However, Wheeler [12] further reported that increased concentration of fungal inoculums offsets any viability-diminishing effects of environmental factors. According to Fernandez [14] temperature and humidity are the main constraints to the effectiveness of fungi. Surfactants such as Tween 80 if appropriately applied allow plants to reduce surface tension and improve the dispersion of the spores in the droplets and therefore increase infection. 
Glycerol is a preservative that has little chemical effect on fungal spores. It immobilizes the spores making infectivity to go down. It's more important role is therefore in preserving fungal spores rather than being used in mycoherbicide formulation.

\section{Conclusion}

Although not a virulent pathogen, A. zonatum has a favorable characteristic for consideration as a mycoherbicide, especially if formulated in appropriate oil emulsion. The use of fungal agent in oil formulation is advantageous as it overcomes the need to physically cover the infected leaves with polythene material to increase moisture for enhanced infection. This study has shown that formulating Acremonium zonatum spore suspension in oil emulsion can make it be used in the innundative control of water hyacinth. Provision of agents that can injure the plants for enhanced infectivity is necessary. A. zonatum can thus be best recommended for use in integrated control of water hyacinth.

\section{Acknowledgement}

We are grateful to all staff of the Kenya Agricultural Research Institute (KARI) Kibos station and all staff of Maseno University, School of biological and physical sciences that made this research possible, many thanks go to Department of Botany, Maseno University staff for providing both the opportunity and support that made this study possible

\section{References}

[1] Opande G. T., Onyango J. C., Wagai S. O., The water hyacinth(Eichhornia crassipes (Mart) Solms, Its socioeconomic effects, control measures and resurgence in the Winam gulf; Limnologica 34, 2004 105-109

[2] Opande, G. O., Distribution of the water hyacinth [Eichhornia crassipes (Mart.) Solms., its carpet characteristics, some of its diseases and pests in the Winam gulf of Lake Victoria. doctoral diss. Maseno University. Maseno, Kenya, 2002.

[3] Womack, G. J., Gillian M. E. and Burge M. N., A vegetable oil based inert emulsion for mycoherbicide delivery. Department of Bioscience and Biotechnology, University of Strathclyde, The Todd Centre, 31 Taylor Street, Glasgow, G4 ONR, UK.2002

[4] Fernandez, O. A. An ecosystem-based regional approach for aquatic weed control. Procc. $3^{\text {rd }}$ International Weed Science Congress 3: 222

[5] Marcondes D. A. S., Pitelli R. A., Martins D., Tanaka R. H., Bronhara A. A. and Mustafa A. L. Velini (Eds)., Recent advances in biology and control of submersed aquatic weeds in Brazil. Procc. $3^{\text {rd }}$ International Weed Science Congress 3, $2000: 220$

[6] Osumo, W. M.., The effect of water hyacinth on water quality in Winam gulf, Lake Victoria. The United Nations University. Reykjavik, 2001

[7] Pitelli, R A., Aquatic weed problems in hydropower systems. Procc. $3^{\text {rd }}$ International Weed Science Congress 3, $2000: 216$.

[8] Olga, F., Moulds and filamentous fungi in technical microbiology; Progress in industrial microbiology, (SNTL publishers of Technical Literature, Prague, 1986 (22).

[9] Caprette R. David, Bioslabs methods/microscopy cell counting, (Rice University, USA, 2000).

[10] Freeman, T.E and Charudattan R., Cercospora rodmanii Conway, a biocontrol agent of water hyacinth. Florida Agricultural Experimental Station Bulletin, FL, (1984) 842.

[11] Karim, D., Rachid L., Mamourou D. and Haissan M.J., Production and oil emulsion formulation of Cadaphora malorum and Alternaria jacinthicola, two biocontrol agents against water hyacinth (Eichhornia crassipes). African Journal of Microbiology Research 5(8), 2011, 924-929.

[12] Wheeler, J.E., Use of emulsified oils for the control of insects and diseases of cacti and succulents. Plant Pathologist, 2010.

[13] Fernandez, C. and Juncosa R., Biopesticides: agriculture of the future Phytomer 141, 2002: 14-19 